\title{
Studi Kasus Kelompok Samasundu dan Tallas dalam Pengelolaan Stereotipe di Sulawesi Barat
}

\author{
Suherli $^{1}$, Tuti Bahfiarti ${ }^{2}$, Muhammad Farid ${ }^{3}$ \\ ${ }^{1}$ Mahasiswa Pascasarjana Ilmu Komunikasi, FISIP, Universitas Hasanuddin, Makasar \\ ${ }^{2}$ Dosen Ilmu Komunikasi, FISIP, Universitas Hasanuddin, Makasar \\ ${ }^{3}$ Dosen Ilmu Komunikasi, FISIP, Universitas Hasanuddin, Makasar \\ E-mail: suherli715@gmail.com
}

DOI: https://doi.org/10.21107/ilkom.v15i1.10163

\begin{abstract}
ABSTRAK
Penelitian ini bertujuan untuk mengidentifikasi bentuk stereotipe kelompok Samasundu terhadap kelompok Tallas di Desa Samasundu, Sulawesi Barat. Stereotipe muncul karena adanya sejarah di masa lalu seperti, stereotipe kelompok Tallas sebagai kelompok yang tidak berpendidikan, kelas sosial bawah serta pekerja kasar. Penelitian ini menggunakan rancangan riset kualitatif dengan pendekatan studi kasus pada kelompok Samasundu dan kelompok Tallas. Data dianalisis dengan kondensasi data, penyajian data, dan penarikan kesimpulan. Hasil penelitian menunjukkan bahwa stereotipe yang selama ini muncul karena adanya kejadian masa lalu kedua kelompok perlahan mulai dapat dihilangkan. Perbaikan dari aspek pendidikan serta ekonomi bagi kelompok Tallas menjadi prioritas utama dengan harapan agar status sebagai kelompok minoritas dapat dihilangkan. Akan tetapi tidak semua aspek sosial yang berkaitan dengan kelas sosial dapat disejajarkan. Ada hal-hal tertentu yang menjadi pengecualian untuk dapat disejajarkan terutama yang berkaitan dengan tradisi ataupun adat yang diyakini oleh keduanya karena kedua kelompok masyarakat masih berpegang teguh pada adat istiadat, seperti acara pernikahan saat proses pelattigian (pemberkatan) bagi seseorang saat melangsungkan pernikahan. Menurut adat istiadat yang diyakini oleh masyarakat setempat, pelattigian (pemberkatan) hanya boleh dilakukan oleh seseorang dengan identitas lebih baik atau mempunyai level sosial paling tidak sama dengan kelompok yang melangsungkan pernikahan. Dalam hal ini, pemerintah setempat atau tokoh masyarakat di desa tersebut harus mampu memberikan solusi berupa pemahaman kepada kelompok Samasundu untuk dapat hidup secara berdampingan tanpa harus melihat kejadian di masa lalu sebagai pembanding diantara kedua kelompok masyarakat sehingga stereotipe yang memberi kesan negatif terhadap kelompok Tallas dapat dihilangkan. Selain itu, kelompok Tallas mempunyai keterampilan unik yaitu membuat keterampilan dari bambu yang tidak dimiliki oleh masyarakat Samasundu harus diberikan pelatihan maupun wadah yang cukup untuk melestarikan atau memberikan inovasi terhadap keterampilan yang mereka miliki.
\end{abstract}

Kata Kunci: studi kasus, stereotipe, Kelompok Samasundu, Kelompok Tallas, kelas sosial

\section{ABSTRACT}

This study aims to identify the stereotypical form of the Samasundu group against the Tallas group in Samasundu Village, West Sulawesi. Stereotypes arise because of histories, such as the stereotype of the Tallas group as an uneducated group, lower social class, and manual workers. This study used a qualitative research design with a case study approach to the Samasundu group and the Tallas group. Data were analyzed by condensing data, presenting data, and drawing conclusions. The results showed that the stereotypes that had emerged due to past events in the two groups were slowly being eliminated.

\section{Cite this as :}

Suherli, Tuti Bahfiarti, Muhammad Farid (2021). Studi Kasus Kelompok Samasundu dan Tallas dalam Pengelolaan Stereotipe di Sulawesi Barat. Jurnal Komunikasi, 15(1), 29-42. doi: https://doi.org/10.21107/ilkom.v15i1.10163

Article History : Received February, $12^{\text {th }}$ 2021, Acepted March, 12 2021 
Improvements in education and economic aspects for the Tallas group are the top priority with the hope that their status as a minority group can be eliminated. However, not all social aspects related to the social class can be equated. Certain things are exceptions to be aligned, especially those related to traditions or customs that are believed by both because the two groups of people still adhere to customs, such as weddings during the training process (blessing) for someone during the marriage. According to the customs believed by the local community, pelattigian (blessing) can only be done by someone with a better identity or having a social level at least the same as the group that is getting married. In this case, the local government or community leaders in the village must be able to provide solutions in the form of understanding to the Samasundu group to be able to live side by side without having to see past events as a comparison between the two community groups so that stereotypes that give a negative impression to the Tallas group can be eliminated. Also, the Tallas group has unique skills, namely making skills from bamboo that are not owned by the Samasundu community, which must be provided with adequate training or a forum to preserve or innovate their skills.

Keywords: case study, stereotype, Samasundu Group, Tallas Group, social class

\section{PENDAHULUAN}

Hidup bermasyarakat merupakan hukum yang telah ditetapkan di dunia ini, yakni menjadi keharusan agar terciptanya hubungan yang harmonis antara sesama dengan mengesampingkan perbedaan yang ada, baik dalam konteks individu maupun kelompok masyarakat. Sejalan dengan hal tersebut, nilai-nilai sosial dapat dipandang sebagai sebagai perubahan sosial dengan mengutamakan kepentingan identitas masyarakat tanpa harus memberikan perlakuan yang sifatnya sebagai suatu legalisasi dalam memandang individu maupun kelompok tertentu. Guna menciptakan hubungan yang harmonis tersebut, kita diharuskan melakukan hubungan sosial dengan orang lain, termasuk dalam aktivitas keseharian. Olehnya, sebagai makhluk sosial agar selalu menjaga komunikasi, baik secara individu maupun secara kelompok. Batasan dalam kelompok masyarakat menjadi salah satu masalah, di mana terdapat jarak yang disebabkan adanya perbedaan pandangan pada masyarakat tertentu. Latar belakang budaya terkadang menjadi salah satu pemicu sehingga timbulnya jarak sosial pada kelompok masyarakat.

Permasalahan yang terjadi karena adanya identitas sosial seringkali dinafikkan fakta bahwa manusia terlahir dengan memperkenalkan identitas budaya, agama ataupun karakter sosial lainnya yang relatif berbeda sehingga melahirkan perbedaan antar individu dan bisa menciptakan kegiatan yang menimbulkan keributan, pergesekan, atau bahkan konflik antar individu maupun kelompok masyarakat. Salah satu pendorong munculnya disintegrasi sosial diwarnai dengan hadirnya relasi sejarah yang relatif kuat melahirkan persoalan sosial tersebut.

Hal tersebut dapat dilihat pada kelompok Samasundu dan kelompok Tallas di Kabupaten Polewali Mandar, Sulawesi Barat di mana masyarakatnya menjalani relasi yang cenderung memicu mbulkan jarak sosial. Samasundu dikenal sebagai kelompok yang cukup dominan dalam proses sosial sedangkan Tallas merupakan kelompok resesif yang didominasi sehingga kedua kelompok masyarakat tersebut mengalami sebuah masalah sosial. Proses ini diawali oleh latar belakang sejarah nenek moyang kedua kelompok masyarakat tersebut, yakni kelompok Tallas dahulunya dianggap sebagai batua (budak) bagi kelompok Samasundu. Masyarakat Tallas adalah kelompok yang tinggal di Desa Samasundu dan diidentikkan sebagai masyarakat satu rupiah. Istilah satu rupiah merupakan pelabelan dari kelompok Samasundu kepada kelompok Tallas menandakan bahwa hidupnya digantungkan sebagai orang yang bisa disuruh untuk melakukan pekerjaan dari majikan kelompok Tallas kemudian diberikan upah. Pemberian label kepada kelompok Tallas menyiratkan arti bahwa harga dirinya begitu rendah saat 
itu. Hal tersebut dapat dilihat dari proses sosial kelompok Tallas yang diposisikan sebagai kelas bawah sebagaimana identitas sebagai kelompok yang tidak berpendidikan. Samasundu dianggap sebagai kelompok mayoritas dan mempunyai peranan sosial cukup dominan di desa tersebut serta kelompok yang mempunyai kedudukan lebih tinggi dibandingkan kelompok Tallas. Kuatnya pemikiran masyarakat mengenai keberadaan kelompok Tallas memunculkan adanya cara berfikir yang membawa kejadian masa lalu sebagai determinan bagi integritas kelompok Samasundu. Melihat berbagai anggapan negatif dari setiap kelompok menyebabkan munculnya jarak sosial. Stereotipe yang diberikan kepada kelompok Tallas sangat berdampak terhadap aktivitas sosial sehingga menimbulkan jarak antara kedua masyarakat tersebut. Sejarah masa lalu dari keduanya telah menghukum kelompok Tallas untuk selalu dianggap sebagai masyarakat kelas bawah sehingga munculnya pembagian pada kedua kelompok masyarakat tersebut. Kelompok Tallas kerap menjadi objek celaan kelompok lain serta diberikan perlakuan berbeda seperti masyarakat Samasundu pada umumnya, hal tersebut yang menyebabkan komunikasi dengan kelompok Samasundu menjadi sangat terbatas bahkan jarang dilakukan.

Stereotipe yang terpelihara kelompok mayoritas berkonsekuensi terhadap perkembangan kelompok Tallas kurang berjalan dengan baik bila dibandingkan dengan masyarakat lain di desa tersebut, salah satu aspek yang paling terasa perbedaannya adalah di sektor pendidikan. Kelompok Tallas belum sepenuhnya mampu keluar dari bayangan masa lalu dengan statusnya yang dianggap sebagai kelompok minoritas sehingga seakan terkurung kejadian tersebut, dan kelompok Samasundu yang tetap melihat latar belakang sejarah sebagai suatu pembanding sosial antara kedua kelompok masyarakat. Fenomena budaya yang terjadi pada kedua kelompok harusnya tidak terjadi dalam suatu kehidupan masyarakat. Bahkan ada anggapan bahwa kelompok Tallas bukan bagian masyarakat Samasundu, padahal secara geografis, Tallas dan Samasundu terletak di daerah yang sama serta memiliki pemerintahan daerah yang sama pula. Dalam cakupan sosial masyarakat, kelompok Tallas bahkan ditempatkan pada kedudukan sosial rendah sebagaimana personalitas mereka sebagai manusia satu rupiah dan batua (budak). Penilaian dapat dilihat dari proses sosial kelompok Tallas yang diposisikan sebagai kelas bawah sebagaimana identitas mereka sebagai batua (budak). Samasundu dianggap sebagai kelompok mayoritas dan mempunyai peranan sosial cukup dominan di desa tersebut serta kelompok yang mempunyai kedudukan lebih tinggi dibandingkan kelompok Tallas. Stereotipe yang muncul dengan adanya pemberian label sebagai kelompok minoritas telah memunculkan stigma negatif terhadap kelompok Tallas yang selama ini mereka dapatkan bahkan menjadi karakter khas ataupun identitas dalam menilai jati diri atau keberadaan kelompoknya.

Penelitian ini bertujuan untuk mengidentifikasi bentuk stereotipe dari kelompok Samasundu terhadap kelompok Tallas di Desa Samasundu, Sulawesi Barat. Stereotipe muncul karena adanya peristiwa masa lalu kedua kelompok masyarakat tersebut yang bermakna negatif. Hal tersebut seakan masih seperti dipertahankan sampai saat ini. Misalnya, stereotipe kelompok Tallas sebagai kelompok yang tidak berpendidikan dan memiliki ekonomi lemah. Adanya stereotipe cenderung menyebabkan masyarakat Tallas akan terus dianggap kurang berkompeten bahkan dianggap rendah pada struktur sosial masyarakat sehingga berkonsekuensi munculnya identitas maupun kelas sosial.

Penelitian mengenai stereotipe telah dilakukan salah satunya (Juditha, 2015) yang berjudul "Stereotip dan Prasangka dalam konflik Etnis Tionghoa dan Bugis Makassar" yang melihat stereotipe dari aspek budaya yang didasarkan pada anggapan bahwa jika kedua etnis dapat menjalin kontak atau interaksi dengan mengembangkan kesalahpahaman budaya dapat menjalin 
kontak atau interaksi dengan mengembangkan komunikasi antar budaya yang bermakna, maka kesalahpahaman budaya dapat diminimalkan sebagai upaya untuk mereduksi perilaku stereotipe, prasangka, dan etnosentris. Hasil penelitian menunjukkan bahwa salah satu jalan keluar dari masalah stereotipe masyarakat Bugis Makassar dan etnis Tioghoa adalah perlunya pemahaman masyarakat mengenai kesadaran multikultural yang merupakan tanggung jawab dari semua aspek. Kesadaran dapat dilakukan dengan adanya sosialisasi oleh pemerintah ataupun masyarakat yang mempunyai kesadaran secara terus menerus kepada etnis Tionghoa, masyarakat Bugis Makassar serta etnis lain yang hidup secara berdampingan. Pengembangan masyarakat di Indonesia perlu didukung oleh kesadaran multikultural, yaitu kesadaran dalam menerima perbedaan serta mengakui dan mampu menerimanya karena kita hidup sebagai masyarakat multikultural dan sebagai masyarakat majemuk dalam hal etnis, budaya dan agama. Penelitian yang mempunyai kemiripan kasus dilakukan juga (Rumondor, Paputungan \& Tangkudung: 2014) yang meneliti tentang "Stereotipe Suku Minahasa Terhadap Etnis Papua (Studi Komunikasi Antarbudaya pada Mahasiswa Fakultas Ilmu Sosial dan Politik Universitas Sam Ratulangi).

Hasil penelitian menunjukkan bahwa stereotipe yang diberikan oleh etnis Minahasa terhadap Etnis Papua umumnya berimbang yakni stereotip bermakna positif dan negatif. Stereotipe positip terhadap etnis papua seperti etnis papua memiliki rasa persatuan yang sangat tinggi, bersifat memberi, religius, setia kawan, dan sangat menghargai adat istiadat. Tetapi ada pula stereotipe negatif yang muncul seperti etnis papua yang susah untuk diajak berinteraksi, suka berkelahi atau mencari masalah, lambat berpikir, mabukmabukan dan cenderung memiliki sifat kasar. Selain melakukan pengumpulan data melalui wawancara dengan informan, penelitian ini juga melakukan observasi atau pengamatan secara langsung terhadap interaksi yang terjadi antara suku Minahasa dan etnis Papua.
Peneliti melakukan pengamatan di area-area publik di sektar gedung Fakultas Ilmu Sosial dan Politik Universitas Sam Ratulangi seperti area lobi, ruang kelas, dan kantin. Dari hasil pengamatan, peneliti mendapati bahwa sangat jarang terlihat etnis Papua berkomunikasi dengan suku Minahasa maupun suku-suku lainnya. Mereka cenderung berkelompok dan memisahkan diri. Sehingga seringkali terlihat kumpulan etnis Papua duduk bergerombol tanpa ada mahasiswa dari suku lain. Hal ini terjadi baik di lobi, dalam kelas, maupun kantin. Peneliti sesekali melihat komunikasi antara suku Minahasa dan etnis Papua terjadi ketika berpapasan untuk saling menyapa satu dengan yang lain. Ketika dalam kelas, interaksi kedua suku pun sangat kurang. Namun ada sedikit perbedaan ketika etnis Papua berinteraksi dalam setiap ibadah yang diadakan setiap minggu oleh organisasi kerohanian kampus saat pertemuan ibadah, etnis Papua bisa berinteraksi dengan baik. Dan sebaliknya, suku Minahasa pun demikian.

Ditemukan tiga faktor yang menjadi penentu terbentuknya oleh mahasiswa yang berasal dari Etnis Minahasa terhadap Etnis Papua, Pertama yakni faktor lingkungan sosial. Lingkungan sosial seperti keluarga dan masyarakat di lingkungan tempat tinggal memberikan pengaruh besar pada pembentukan stereotipe keduanya. Yang kedua adalah faktor pengalaman individu yang membentuk stereotip informan. Menurut seorang psikolog George Kelly, pengalaman diciptakan oleh cara kita menafsirkan peristiwa dan setiap orang berbeda-beda satu sama lain dalam menginstruksi peristiwa. Faktor yang ketiga adalah faktor kontak pribadi yang lebih intim. Yaitu komunikasi yng dilakukan dengan saling percaya untuk mendapatkan komunikasi interpersonal diantara kelompok yang berkomunikasi karena akan membuka sarana komunikasi dan peluang untuk mencapai tujuan komunikasi menjadi terbuka. Saling percaya akan memberikan pengertian satu sama lain dan menciptakan keberhasilan dalam budaya komunikasi antar individu ataupun kelompok. 
O’Sullivan dalam (Anshori, 2017: 131) memandang bahwa Stereotipe sering dipahami sebagai proses klarifikasi sosial yang dilakukan oleh sebagian kelompok dangan cara terlalu menyederhanakan atau menggenerelisasikan tanda-tanda, baik secara eksplisit atau implisit merepresentasikan nilai-nilai, keputusan, atau asumsi yang berpusat pada perilaku mereka, karakteristik, atau sejarah masa lampau. Stereotip juga dapat diartikan sebagai konsepsi mengenai sifat suatu golongan berdasarkan prasangka subjektif dan tidak tepat. Stereotip terjadi karena proses kognisi dalam mengategorisasikan sesuatu berdasarkan sikap, nilai, dan pengalaman seseorang. Oleh karena itu, mengategorisasikan dan mengidentifikasi merupakan kata kerja yang dilakukan sesesorang dalam melabeli atau menggenerelisasikan pihak lain. Stereotip bermakna luas, bukan hanya dalam mengategorisasikan manusia berdasarkan bangsa, ras, kelas sosial, gender, pekerjaan, dan kelompok, tetapi juga berkait dengan halhal yang dapat dikelompokkan (undifferentiaded judgment). Mulyana dalam (Anshori, 2017: 131-132) mengatakan klarifikasi memberi jarak persepsi dan bersifat diametra, dilain pihak stereotip tercipta karena satu budaya tertentu menggenerelisasikan budaya lain. Dengan demikian, orang akan dapat menghindari stereotip dengan mengumpulkan sejumlah informasi tentang objek yang dinilai, disikapi, atau dipersepsinya suapay generalisasi yang dilakukan mendekati fakta-faka objektif. Kemalasan mencari dan mengumpulkan data akan berakibat pada sempit dan dangkalnya pandangan kita atas objek yang dipersepsi.oleh karena itu, stereotip umumnya berimplikasi negatif bagi pihak yang dipersepsinya.Stereotip dapat positif ataupun negatif. Stereotip yang merujuk sekelompok orang sebagai orang malas, Kasar, jahat atau bodoh jelas-jelas merupakan stereotip negatif. Tentu saja, ada stereotip yang positif, seperti asumsi pelajar dari Asia yang bekerja keras, berkelakuan baik, dan pandai. Bagaimanapun, karena stereotip mempersempit persepsi kita, maka stereotip dapat mencemarkan komunikasi antar budaya. Hal ini karena stereotip cenderung untuk menyamaratakan ciri-ciri sekelompok orang. Misalnya, kita tahu bahwa tidak semua pelajar Asia yang pekerja keras, dan pandai, dan tidak ada sekelompok orang yang semuanya pemalas.

Stereotipe dapat mengembangkan rasa takut terhadap orang di luar kelompoknya. Misalnya, banyak orang melihat seseorang yang catat mental rentan cenderung melakukan kekerasan. Konflik ini dilengkapi dengan data secara statistik menunjukkan bahwa orang cacat mental sam rentannya melakukan kekerasan dengan orang normal lainnya. Namun, karena publikasi mengenai orang cacat mental membunuh orang lain, stereotip mengenai hal ini menjadi suatu aturan dibandingkan suatu pengecualian. Oleh karena inilah, mengapa banyak stereotip yang berkembang untuk peratam kalinya; sejumlah perilaku tertentu yang dilakukan oleh anggota suatu kelompok melahirkan persepsi umum yang mewakili semua anggota kelompok tersebut (Samovar dkk 2010: 203-205).

Stereotip terbangun melalui budaya yang diyakini pihak lain. Misalnya laki-laki Sunda tidak baik menikah dengan perempuan Jawa karena mereka akan terkuasai perempuan Jawa. Betulkah demikian faktanya? Disaat pernikahan campuran (bahkan antarbangsa) sedang menjadi kecenderungan, stereotip ini terlalu usang untuk diyakini. Secara ilmiah, stereotip ini juga belum ada yang bisa membuktikannya, seberapa banyak perempuan Jawa menguasai laki-laki Sunda. Kalau pun ada yang demikian, faktor-faktor yang menyebabkan terjadinya penguasaan tersebut. Demikian pula mesti dikaji sebaliknya, berapa banyak perempuan Jawa yang terkuasai laki-laki Sunda dan faktor apa yang menyebabkannya.

Stereotip dibangun dari waktu ke waktu, yang mana setiap kelompok masyarakat mempunyai kerangka interpretasi sendiri-sendiri berdasarkan lingkungan budaya. Streotip biasanya merupakan referensi pertama (penilaian umum) ketika sesorang atau kelompok melihat orang atau 
kelompok lain. Stereotip akhirnya merupakan penghambat potensial dalam komunikasi antarbudaya. Suatu contoh penilaian orangorang Jepang terhadap kelompok minoritas Burakumin di Jepang, yang menilai bahwa sebuah perkawinan dengan orang-orang Burakumin dianggap sebagai kesalahan (Purwasito 2015)

Stereotipe dapat dihilangkan dengan mengumpulkan data sebanyak mungkin sehingga kita dapat meyakini, apakah peristiwa itu betul atau hanya mitos belaka. Dalam hal contoh di atas kita dapat melihat secara logis tentang "kuasa-menguasai" ini dalam konteks relasi individu dan sosial. Setiap orang memiliki peran lebih besar (autority), baik dari aspek pendidikan, sosial, ekonomi, dan tanggung jawab akan tampak dominan dibandingkan dengan yang lain. Laki-laki Sunda yang kemampuan ekonominya rendah dibandingkan perempuan Jawa, tentu keluarganya tidak akan lebih dominan. Demikian, pula laki-laki Sunda yang tingkat pendidikannya lebih rendah, tanggung jawab dan relasi sosisalnya kurang, kemampuan memutuskan maslah lambat, atau tingkat ketergantungannya lebih tinggi akan subordinat dalam kehidupan rumah tangganya. Relasi ini jauh lebih dapat dipahami secara nalar mengingat faktor-faktor tersebut yang menentukan siapa menguasai siapa. Meskipun demikian, dalam sebuah keluarga seharusnya bukan hadir konsep kekuasaan, tetapi konsep kehormonian antara dua pihak berbeda latar.

De Foster dan Hernacki dalam (Anshori, 2017: 133) memberikan contoh stereotipe orang berkacamata lebih pintar atau perempuan bule berambut pirang lebih bodoh juga tidak dapat dibuktikan dengan hanya melihat ukuran kacamata atau warna rambut. Tidak ada tulisan yang mengorelasikan antara kacamata dan warna rambut dengan kecerdasan seseorang. Sangat mungkin seseorang berkacamata bukan karena banyak membaca, tetapi terkena radiasi televisi atau layar komputer, mungkin pula karena intelegensinya rendah atau kerena tidak rajin belajar. Warna rambut tidak ada kaitannya dengan peristiwa fisik tersebut. Cerdas dan bodoh lebih merupakan implikasi dan rajin tidaknya seseorang belajar. Seseorang dapat memiliki kecerdasan yang berbeda, apakah linguistik, matematika, visual/spasial, kinestetik, musikal, interpersonal, intrapersonal, atau intuisi. Demikian banyak stereotip di masyarakat yang bermuara pada pandangan budaya dan kepercayaan subjektif (keyakinan intuitif) terhadap kelompok masyarakat tertentu. Oleh karena itu, stereotip lebih tepat dijelaskan sebagi gambaran yang ada di kepal seseorang tentang sebuah kecenderungan budaya dan nilai kelompok masyarakat. Betapa pun cenderung negatif stereotip tidak terlalu berbahaya dalam batasbatas tertenyu, namun apabila dijadikan sebagai keyakinan hidup maka penagnut stereotip akan mendapatkan bahwa pandangannya tidak selalu benar secara faktual, bahkan cenderung merugikan.

Pada beberapa contoh stereotipe di masyarakat, kita dapat melihat identitas pada masyarakat tersebut. Kesalahan persepsi dapat terjadi pada masyarakat yang menggunakan rujukan budaya dan keyakinan historis sebagai panduan, tanpa mengkaji kembali perkembangan dan informasi akurat tentang budaya kelompok masyarakat. Stereotip berkembang sebagai folklor (cerita) di masyarakat dan diyakini kebenarannya, terutama oleh pihak-pihak yang tidak memiliki data akurat. Terlepas dari adanya kekeliruan tersebut, penting diketahui bagi pengkaji budaya bahwa perilaku berbahasa mereka akan menggambarkan satu karakteristik yang stereotip, baik dalam bahasa formal maupun humor (anekdot). Terkadang stereotip digambarkan dengan baik melalui struktur-struktur pengetahuan yang mempelajari mengenai kelompok sosial yang secara sederhana kemudian dimunculkan di permukaan, akan tetapi di lain waktu stereotip tersebut dikonstruksi di dalam suatu koteks dari sumber yang tersedia. Russell Spears beragumen bahwa jika yang diinginkan adalah melihat bagaimana stereotip terbentuk, maka seseorang seharusnya menganggapnya lebih dinamis dan proses sosial yang menentukan hubungan diantara kelompok, 
bagaimana makna yang digali, dikonstruksi dan berkembang dari waktu ke waktu. Jhonson dalam ((Liliweri, 2017: 228) mengemukakan stereotipe adalah keyakinan seseorang untuk menggenarasikan sifat-sifat tertentu yang cenderung negatif tentang orang lain karena dipengaruhi oleh pengetahuan dan pengalaman bersama.keyakinan itu membuat seseorang untuk meperkirakan perbedaan antar kelompok yang mungkin kelewat tinggi atau kelewat rendah sebagai ciri khas individu atau kelompok sasaran.

Stereotip merupakan hasil dari kategorisasi yang kita lakukan, misalnya menggambarkan tentang jenis karakteristik ras atau etnik lain. Miles Hewstone dan Rupert Brown dalam (Liliweri, 2017: 228) mengemukakan ada tiga aspek esensial dari stereotipe, yakni acap kali keberadaan individu dalam suatu kelompok telah dikategorisasi, dan kategorisasi itu selalu terindetifikasi dengan mudah melalui karakter/ sifat tertentu, misalnya perilaku, kebiasaan bertindak, orientasi seksual, maupun etnisitas, stereotip bersumber dari suatu bentuk atau sifat perilaku yang bersifat turun temurun sehingga dia seolah-olah melekat untuk semua anggota kelompok, karena itu individu yang merupakan anggota dari suatu kelompok diasumsikan memiliki karakteristik, ciri khas, kebiasaan bertindak yang sama dengan kelompok yang digeneralisasi itu. Stereotipe yang muncul karena adanya sejarah masa lalu menimbulkan sebuah stratifikasi sosail dan kelas pada kedua kelompok masyarakat tersebut. Kesan yang selama ini muncul bahwa kelompok Tallas adalah kelompok kecil yang berbeda dengan kelompok Samasundu seakan menimbulkan rasa kurang percaya diri kelompok Tallas bila melakukan sebuah hubungan sosial dengan kelompok di luar komunitasnya.

Teori identitas sosial (social identity theory, SIT) pertama kali diperkenalkan oleh Taijfel dan Turner dalam (Liliweri, 2018: 495-496). Teori ini bertujuan untuk menjelaskan afiliasi seseorang dalam kelompok sosial, termasuk menjelaskan perilaku sosial mereka didalam kelompok tersebut. Teori identitas sosial merupakan analisis psikologi sosial tentang peran konsep diri dalam penguasaan kelompok, proses kelompok, dan hubungan antarkelompok (Hogg, Terry White, 1995).Teori identitas sosial berfokus pada hubungan antara konsep diri dan perilaku kelompok (Hogg \& Terry, 2001) teori ini menjelaskan bahwa berbagai aspek kepribadian individu memotivasi mereka pada waktu yang berbeda, dan bahwa amotivasi dari identitas akan diputuskan oleh situasi tertentu dari individu dengan mengandalkan identitas pribadi atau sosial. Henri Tajfel mengusulkan teori ini sebagai hasil kerja yang telah dilakukan di tahun 1970-an mengenai "kategorisasi dan persepsi sosial, perilaku antar kelompok, dan pemahaman psikologis sosial tentang penyebab prasangka dan konflik antar kelompok" (Abrams \& Hogg, 1999). Tajfel, dkk (1971) mencoba untuk mengidentifikasi kondisi minimal yang akan menyebabkan anggtota satu kelompok yang mereka tempati, terhadap kelompok lain.

Tajfel yakin bahwa individu tidak konsisten bagaimana mereka berperilaku saat berhubungan dengan orang lain dalam lingkungan antara kelompok, menentang aturan antara personal dan berusaha menjelaskan perilaku orang-orang dalam situasi kelompok (Abrams \&Terry, 2001). Tajfel mengidentifikasi tiga komponel identitas sosial (1) Konseptualisasi diri; (2) Harga diri kelompok; (3) Komitmen terhadap kelompok yang ketika bertemu menyebabkan seseorang merasa terhubung dengan Ingroup mereka. Akibatnya, semua kelompok lain menjadi kelompok bebas dan merupakan saingan untuk pemerolehan status dan sumber daya, sekaligus sebagai sumber perbandingan (Redmond, 2009). Konseptual dan teoritikal merupakan panduan dalam menjawab fokus permasalahan penelitian, yaitu: bagaimana bentuk stereotipe yang terjadi antara kelompok Samasundu terhadap kelompok Tallas dalam konteks komunikasi diantara kedua kelompok masyarakat. Henri Tajfel dalam (Liliweri 2018) mengusulkan teori ini sebagai hasil kerja yang telah dilakukan di 
tahun 1970-an mengenai "kategorisasi dan persepsi sosial, perilaku antar kelompok, dan pemahaman psikologis sosial tentang penyebab prasangka dan konflik antar kelompok" (Abrams \&Hogg, 1999). Tajfel, dkk (1971) mencoba untuk mengidentifikasi kondisi minimal yang akan menyebabkan anggtota satu kelompok yang mereka tempati, terhadap kelompok lain.

Fokus permasalahan pada penelitian ini bertujuan untuk mengidentifikasi dan mengkategorisasi bentuk stereotipe yang terjadi diantara kedua kelompok masyarakat dalam kaitannya dengan peristiwa sejarah di masa lalu antara kedua kelompok masyarakat yang sampai saat ini pandangan terhadap kelompok Tallas sebagai kelompok yang mendapat stereotipe seakan masih bertahan hingga saat ini. Kuatnya pemikiran yang terjadi karena stigma negatif tersebut menjadi asumsi bagi peneliti dalam melihat hal tersebut sebagai acuan untuk memberikan gambaran mengenai keadaan yang terjadi pada kedua kelompok masyarakat tersebut sehingga memberikan hal baru untuk meihat fakta-fakta yang sebenarnya yang kemudian dijadikan dasar dalam memberikan pandangan terhadap hal yang sebenarnya terjadi di lapangan.

\section{METODE PENELITIAN}

Penelitian ini menggunakan rancangan riset kualitatif, yaitu mengumpulkan data berupa rincian cerita yang disampaikan oleh responden penelitian dan diungkapkan apa adanya sesuai dengan bahasa dan pandangan dari setiap responden (Hamidi: 2010). Penelitian ini menggunakan pendekatan studi kasus bertujuan untuk mengontrol peristiwaperistiwa yang akan diselidiki dan fokus penelitian terletak pada fenomena dalam konteks kehidupan nyata (Yin 2008). Penelitian studi kasus yaitu melakukan ekplorasi mendalam terhadap kisah hidup individu atau kelompok melalui kasus yang variatif (Creswell: 2014).

Melihat pandangan atau pun pendapat diatas dapat digambarkan bahwa studi kasus lebih menekankan pada suatu kasus. Mengenai kasus yang dimaksud dalam penelitian ini adalah semua pendapat di atas menggambarkan bahwa metode studi kasus lebih menitik beratkan pada suatu permasalahan yang ada kemudian dieksplorasi secara mendalam serta melibatkan berbagai sumber informasi dengan tujuan mendapatkan informasi secara tepat kemudian mengeksplorasi mendalam terhadap individu atau kelompok melalui stereotipe yang selama ini muncul. Pengumpulan data lapangan dilakukan melalui observasi, wawancara mendalam dan melibatkan sumber informasi yang kredibel terhadap masalah tersebut.

Subjek dalam penelitian ini adalah masyarakat Samasundu dan Tallas yang tinggal di Desa Samasundu dengan rincian informan Samasundu sebanyak 5 orang, kelompok Tallas sebanyak 4 orang serta tokoh masyarakat sebanyak 4 orang. Penentuan informan dipilih sesuai dengan fokus yang dibicarakan yaitu mengetahui dan mempunyai ikatan dengan masalah penelitian diantara kedua kelompok masyarakat tersebut, yaitu masyarakat asli Samasundu dan Tallas yang mempunyai pengetahuan yang cukup mengenai sejarah serta penduduk asli yang memiliki kapasitas untuk menjelaskan mengenai objek penelitian. Selain itu kriteria informan dipilih berdasarkan ketersediaan dalam memberikan jawaban yang akurat dan refresentatif sesuai dengan masalah dan tujuan penelitian. Hal ini dimaksudkan agar data yang nantinya akan diperoleh memiliki kredibilitas yakni kriteria untuk memenuhi nilai kebenaran dari data dan informasi yang dikumpulkan.

Objek penelitian ini berfokus pada bentuk stereotipe dari kelompok Samasundu terhadap kelompok Tallas di Desa Samsundu. Teknik pengumpulan data penelitian, pertama; observasi partisipan, yakni peneliti terlibat langsung mengamati rutinitas subjek penelitian dalam konteks komunikasi kelompok Samasundu dan Tallas. Kedua, wawancara mendalam sebagai suatu proses agar peneliti mendapatkan informasi secara 
akurat dari informan penelitian. Proses tersebut dilakukan sebagai suatu cara untuk memperoleh keterangan dengan cara tanya jawab secara langsung dengan informan dengan memiliki keterlibatan tinggi dalam kehidupan informan serta interaksi secara langsung antara peneliti dengan informan atau memiliki keterlibatan tinggi dalam kehidupan informan. Ketiga, dokumen berupa catatancatatan sejarah (Alwasilah, 2018: 10).

Dokumen atau peristiwa sejarah tersebut berupa cerita-cerita masyarakat Samasundu dan sebagainya. Teknik analisis data menggunakan model interaktif Miles dan Huberman dengan tiga langkah, antara lain: pertama, Kondensasi data yaitu merujuk pada proses untuk menyeleksi, menyederhanakan, mengabstraksi, dan mentransformasi data yang mendekati keseluruhan bagian dari catatan lapangan secara tertulis, transkrip wawancara,dokumen-dokumen yang ada dan didapat dari materi-materi empiris. Kesimpulannya bahwa proses kondensasi data ini diperoleh setelah peneliti melakukan wawancara dan medapatkan data tertulis yang ada di lapangan, yang nantinya transkrip wawancara tersebut dipilah-pilah untuk mendapatkan fokus penelitian yang dibutuhkan peneliti.

Hasil kondensasi data mengumpulkan data-data yang relevan dengan bentuk stereotipe yang muncul dari kelompok Samasundu dan Tallas dalam konteks komunikasidari kedua kelompok tersebut di Desa Samasundu. Selanjutnya kedua, tahapan penyajian data merupakan hasil dari kondensasi data telah disajikan dengan sistematis dan memiliki keterikatan logis. Penyajian data dapat dilakukan dengan pensyatuan dan infromasi yang disimpulkan. Penyajian data disini juga membantu peneliti dalam memahami konteks penelitian karena melakukan analisis yang lebih mendalam. Ketiga, penarikan kesimpulan atau verifikasi data Penarikan kesimpulan disini dilakukan peneliti dari awal mengumpulkan data seperti mencari pemahaman yang tidak memiliki pola, mencatat keteraturan penjelasan, dan alur sebab akibat, dan tahap akhirnya disimpulkan keseluruhan data yang diperoleh peneliti. Penarikan kesimpulan dilakukan ketika data sudah benar-benar valid sehingga data dapat dijadikan sebagai kesimpulan akhir (Miles, Huberman \& Saldana 2014)

\section{HASIL DAN PEMBAHASAN}

Penelitian stereotipe kelompok Samasundu terhadap kelompok Tallas di Desa Samasundu menggunakan pendekatan studi kasus. Fokus penelitian dalam kehidupan nyata melibatkan peneliti dalam proses penemuan informasi sehingga mendapatkan sumber yang objektif dapat dilihat ketika melakukan wawancara dengan proses interaksi yang dilakukan tidak terbatas dengan kedua kelompok tersebut terutama masyarakat Samasundu. Budaya yang cukup kental masih dipegang teguh oleh informan penelitian dengan bersikap ramah sebagai sesuatu hal yang diterapkan dalam proses wawancara. Berdasarkan hasil penelitian menemukan dan mendeskripsikan identitas diri dari 5 informan penelitian, yakni 2 masyarakat Samasundu dan 2 masyarakat Tallas serta 1 tokoh masyarakat dengan jumlah keseleluruhan informan sebanyak 12 orang Desa Samasundu yang diuraikan dalam tabel berikut.

Tabel I Karakteristik Informan

\begin{tabular}{|cllc|}
\hline No & $\begin{array}{c}\text { Informan } \\
\text { (Inisial) }\end{array}$ & \multicolumn{1}{c|}{ Jenis informan } & Umur \\
\hline 1 & HR & Kelompok Samasundu & 47 \\
\hline 2 & SR & Kelompok Samasundu & 52 \\
\hline 3 & KY & Kelompok Tallas & 49 \\
\hline 4 & KC & Kelompok Tallas & 47 \\
\hline 5 & HB & Tokoh masyarakat & 54 \\
\hline 6 & SP & Kelompok Samasundu & 48 \\
\hline 7 & AW & Kelompok Samasundu & 41 \\
\hline 8 & SK & Kelompok Tallas & 49 \\
\hline 9 & ETL & Kelompok Tallas & 46 \\
\hline 10 & AF & Tokoh Masyarakat & 44 \\
\hline 11 & AD & Tokoh masyarakat & 66 \\
\hline 12 & SY & Kelompok Samasundu & 50 \\
\hline
\end{tabular}

Berdasarkan karakteriktik informan, HD (inisial) berasal dari Samasundu berumur 47 tahun berprofesi sebagai pegawai negeri 
sipil. HD memiliki 4 orang anak dan mengaku memiliki beberapa teman yang berasal dari kelompok Tallas. HD menceritakan bahwa stereotipe yang selama ini diberikan kepada kelompok Tallas begitu menyedihkan dan harus dihilangkan. Ia memandang bahwa stigma negatif kelompok Tallas seperti kelompok yang tidak berpendidikan, pekerja kasar, bahkan dianggap batua (budak) tidak memiliki alasan mendasar untuk tetap dipertahankan oleh masyarakat mayoritas. Menurutnya, kisah yang terjadi diantara nenek moyang kedua kelompok tersebut harus dihapuskan karena saat ini kelompok Tallas sudah berkembang terutama yang berkaitan dengan aspek yang yang selama ini disangkakan kepada kelompoknya. Informan kedua bernama SR (inisial) merupakan warga Samasundu yang berumur 50 tahun kesehariannya berprofesi sebagai petani. Ia menceritakan bahwa budaya gengsi dalam hubungannya dengan masyarakat Tallas telah menimbulkan adanya jarak sosial yang terjadi antara kedua kelompok masyarakat tersebut. Misalnya tradisi pernikahan yang nyaris tidak akan pernah terjadi diantara kedua kelompok masyarakat tersebut mengingat adanya peristiwa sejarah yang sehingga memberikan jarak diantara kedua kelompok masyarakat. Informan ketiga, bernama KY (inisial) berasal dari kelompok Tallas berusia 49 tahun, kesehariannya berprofesi sebagai penjual ikan keliling kampung dengan cara dipikul. KY menjelaskan pendidikan terakhirnya secara rinci yakni hanya sampai di kelas 1 tingkat sekolah dasar (SD). KY begitu antusias menceritakan kepada peneliti mengenai alasan bersekolah hanya sampai di tingkat kelas 1 sekolah dasar (SD) karena tidak ada motivasi dari orang tuanya dalam memberikan pemahaman mengenai pentingnya sebuah pendidikan. Selain itu, ada hal lain yang menyebabkan sehingga KY memutuskan berhenti bersekolah karena saat itu ia merasa sering diperlakukan jahat oleh teman sekolahnya yang merupakan kelompok Samasundu. KY merasa takut untuk bersekolah mengingat letak sekolahnya berada di wilayah Samasundu sehingga rasa takut tersebut selalu ada.
Informan keempat bernama $\mathrm{KC}$ (inisial) berusia 47 tahun berasal dari Tallas, profesinya sebagai penjual sayur-sayuran di daerah Kabupaten Majene. KC merupakan suami dari informan KY. Pendidikan terakhir KC juga hanya sampai di tingkat kelas 2 Sekolah Dasar (SD) sehingga tidak mampu membaca dan menulis. Sama seperti alasan yang diungkapkan $\mathrm{KY}$, penyebab berhenti bersekolah karena KC merasa bahwa dunia pendidikan tidak penting baginya dan keluarganya dan kelompoknya yang lain, selain itu KC merasa minder dan kurang percaya diri dalam berbaur dengan kelompok Samasundu hal ini dilatarbelakangi karena KC merasa kurang percaya diri ketika harus berbaur ataupun berteman dengan kelompok yang berasal dari Samasundu. Informan kelima bernama, HB (inisial) seorang tokoh masyarakat di desa tersebut, berusia 55 tahun kesehariannya berprofesi sebagai seorang guru di salah satu Sekolah Dasar (SD) di Samasundu dan mayoritas muridnya berasal dari Samasundu dan Tallas. HB mengatakan bahwa memang ada jarak yang begitu besar dari segi kualitas pendidikan diantara kedua kelompok masyarakat tersebut. Kelompok Samasundu dianggap memiliki kecerdasan lebih diatas dibandingkan dengan masyarakat Tallas yang bersekolah di SD tersebut. HB mengisahkan kejadiannya berdasarkan pengalaman mengajar atau pun menjadi seorang Guru selama 20 tahun di sekolah tersebut. Selain sebagai Guru, HB juga dianggap sebagai papuangan (pemangku adat) di Desa Samasundu. HB menceritakan bahwa fenomena unik yang terjadi diantara kedua kelompok masyarakat tersebut di masa sehingga menimbulkan stereotipe yang bermakna negatif terhadap kelompok Tallas yang berdampak terhadap aktivitas sosial mereka yang mengalami masalah. Stereotipe yang muncul sengat berperan penting dalam kaitannya dengan hubungan sosial kedua kelompok masyarakat ini yang terasa menimbulkan jarak sosial.

HB memberikan contoh ketika salah seorang masyarakat Samasundu mengadakan hajatan atau pun pernikahan, menurut 
informan HB, Kelompok Tallas tidak bisa memberikan pelattigian (pemberkatan) kepada kelompok Samasundu yang melangsungkan hajatan atau pun pernikahan tersebut. Karena menurut $\mathrm{HB}$ prosesi pelattigian (pemberkatan) merupakan sesuatu yang sifatnya sakral dan tidak bisa dilakukan oleh sembarang orang. Dengan demikian prosesi pelattigian tersebut tidak bisa tidak bisa dilakukan oleh kelompok Tallas bila yang melangsungkan hajatan atau pun pernikahan adalah masyarakat Samasundu karena hal tersebut sudah menjadi hal yang dianggap lumrah dan telah menjadi budaya bagi kedua kelompok masyarakat di desa tersebut. Melihat fenomena yang saat ini terjadi mengenai stereotipe terhadap kelompok Tallas dan beberapa orang juga memandang bahwa masyarakat Tallas sebagai pekerja keras, giat dan tangguh dalam memenuhi kebutuhan hidupnya. Stereotipe beberapa masyarakat Samasundu mengenai posisi masyarakat Tallas tetap berada di bawah status sosial kelompok Samasundu mendapatkan pertentangan sehingga stereotipe menjadi hal yang harusnya dapat dihilangkan menurut beberapa masyarakat Samasundu dan tokoh masyarakat Samasundu.

Stereotipe seperti yang dipahami oleh beberapa kelompok Samasundu antara lain adalah bahwa kelompok Tallas tidak bisa menikah dengan kelompok Samasundu karena terhalang sejarah sosial. Stereotipe itu dimaknai oleh beberapa fakta yang terjadi bahwa justru sebenarnya bahwa saat ini ada beberapa kelompok Tallas yang melangsungkan pernikahan dengan kelompok Samasundu ataupun menjalani biduk rumah tangga berdasarkan pengamatan peneliti dilapangan. Selain itu, tokoh masyarakat Samasundu justru memandang bahwa stereotipe tersebut bisa menjadi motivasi bagi kelompok Tallas untuk setidaknya secara sosial bisa naik kelas dengan meningkatkan kemampuan ekonomi sehingga stereotipe sebagai kelompok yang secara sosial berada dibawah Samasundu perlahan dapat dihilangkan dengan kemampuan finansial mereka. Perlu diketahui bahwa di dunia pendidikan saat ini kelompok Tallas sebenarnya belum bisa dikatakan masuk kategori sama dengan kelompok Samasundu. Seperti yang diungkapkan oleh informan HR salah seorang guru di Samasundu. HR mengungkapkan jika dibandingkan dengan 10-30 tahun kebelakang, saat ini status kelompok Tallas sudah berada pada tahap perkembangan meskipun hanya beberapa orang saja yang melanjutkan pendidikan setidaknya di tingkat sekolah menengah atas (SMA/sederajat). Perbaikan diri dari aspek pendidikan dan ekonomi menjadi prioritas utama bagi kelompok Tallas dalam menghapus pandangan negatif dari kelompok mayoritas tujuannya agar menciptakan kelas sosial yang sejajar dengan kelompok Samasundu.

Berdasarkan hasil pengidentifikasian di lapangan ditemukan bahwa munculnya stereotipe yang diakibatkan oleh sejarah masa lalu nenek moyang kedua kelompok masyarakat tersebut telah menimbulkan sebuah stigma negatif terhadap kelompok Tallas yang hingga saat ini masih bertahan. Akibat bentuk stereotipe tersebut menimbulkan rasa kurang percaya diri kelompok Tallas ketika ada kegiatan yang mengharuskan adanya interaksi ataupun komunikasi dengan kelompok Samasundu sehingga menimbulkan sikap kurang yakin terhadap kegiatan yang dilakukan. Perbaikan diri dari aspek pendidikan dan ekonomi menjadi prioritas utama bagi mereka dalam menghilangkan stereotipe yang selama ini menjadi penilaian baku dari kelompok Samasundu. Selanjutnya stereotipe yang berkembang di masyarakat menyebabkan terjadinya suatu hubungan sosial diantara kedua kelompok tersebut sehingga adanya sebuah orientasi ataupun penilaian yang bermakna negatif seperti, munculnya kelompok-kelompok di masyarakat serta kelas sosial yang bisa menimbulkan jarak sosial ataupun kelas sosial mengenai keberadaan kelompok Tallas sebagai kelompok yang mendapatkan stereotipe.

Hasil penelitian menunjukkan tingkatan ataupun bentuk stereotipe yang 
selama ini menjadi identitas kelompok Tallas. Hasil penelitian mengasumsikan bahwa kelompok Samasundu pada moment-moment tertentu akan tetap melihat peristiwa sejarah masa lalu sebagai pandangan dalam pengambilan keputusan, seperti acara nikahan ataupun pelattigian (pemberkatan) bagi seseorang yang melangsungkan pernikahan, dengan membenarkan adat istiadat ataupun tradisi yang selama ini diyakini oleh kedua kelompok tersebut. Asumsi bentuk stereotipe yang cenderung mengakibatkan adanya kelas dan identitas sosial didasarkan pada gagasan teoritik yang dikembangkan oleh Tajfel dan Turner mengenai teori identitas sosial. Teori ini bertujuan untuk menjelaskan afiliasi seseorang dalam kelompok sosial, termasuk menjelaskan perilaku sosial mereka didalam kelompok tersebut. Teori identitas sosial merupakan analisis psikologi sosial tentang peran konsep diri dalam penguasaan kelompok, proses kelompok, dan hubungan antarkelompok (Hogg, Terry White, 1995). Menurut Tajfel dan Turner bahwa perilaku sosial pada kelompok Tallas muncul karena adanya stereotipe yang diberikan oleh kelompok Samasundu dan kelompok Tallas merasa bahwa adanya stereotipe yang dialamatkan kepada kelompoknya menyebabkan munculnya perilaku sosial didalam kelompok tersebut. Teori ini dijelaskan mengenai "kategorisasi dan persepsi sosial, perilaku antar kelompok, dan pemahaman psikologis sosial tentang penyebab prasangka dan konflik antar kelompok" (Abrams \&Hogg, 1999).

Tajfel, dkk (1971) mencoba untuk mengidentifikasi kondisi minimal yang akan menyebabkan anggota satu kelompok yang mereka tempati, terhadap kelompok lain. Dalam hal ini, Samasundu sebagai kelompok yang memberi dan percaya bahwa stereotipe mengenai kelompok Tallas seperti kelompok yang tidak berpendidikan, kelas sosial yang berbeda, bahkan dianggap sebagai batua (budak) telah menimbulkan munculnya perilaku yang tidak konsisten dalam berperilaku baik saat berhubungan dengan keompoknya maupun orang lain dalam kelompok. Komponen yang dimunculkan yaitu konseptualisasi diri, harga diri kelompok dan Komitmen terhadap kelompok yang ketika bertemu menyebabkan seseorang merasa terhubung dengan Ingroup mereka. Akibatnya, mereka merasa bahwa kelompok Lain merupakan saingan dalam memperoleh status yang diyakini lebih tinggi.

\section{PENUTUP}

Hasil penelitian ini mengidenfikasikan bentuk stereotipe kelompok Samasundu terhadap kelompok Tallas yang menimbulkan stigma negatif dan kemudian berkonsekuensi munculnya hubungan yang cenderung kesan jarak sosial serta adanya stratifikasi ataupun kelas sosial pada kedua kelompok tersebut. Dampak yang terjadi dengan adanya stereotipe tersebut sangat dirasakan oleh kelompok Tallas karena mereka selalu dibayangi oleh peristiwa di masa lalu yang hingga saat ini belum sepenuhnya bisa dihilangkan dari kehidupan kelompok Tallas. Tetapi upaya resistensi ataupun perlawanan dilakukan dalam memutus stereotipe atau pun pandangan yang sifatnya negatif selama ini dialamatkan kepada kelompoknya. upaya tersebut dimulai dari perbaikan diri dari aspek pendidikan dan ekonomi. Harapan yang ingin dicapai dengan baiknya kedua sektor tersebut agar stereotipe yang sifatnya negatif selama ini ditujukan kepada kelompok Tallas segera dihilangkan dan kelompok Tallas bisa hidup secara berdampingan dengan kelompok yang dianggap mayoritas di Desa Samasundu.

\section{DAFTAR PUSTAKA}

Alwasilah, A. Chaedar. 2015. Pokoknya Studi Kasus: Pendekatan Kualitatif. Bandung: Kiblat Buku Utama.
Anshori, Dadang. 2017. Etnografi Komunikasi Perspektif Bahasa. Jakarta: RajaGrafindo Persada. 
Bahfiarti, Tuti. 2020. Kegelisahan dan Ketidakpastian Narapidana dalam Konteks Komunikasi Kelompok Budaya Bugis Makasssar. Jurnal Kajian Komunikasi. Volume 8: 34.

Basyir, Jalaluddin. 2018. Membaca Identitas Lewat Akselerasi Sosial Masyarakat Tallas. 2018. Prosiding Seminar Nasional Dakwah dan Komunikasi, Volume 8: 143-145.

Creswell, J. W. 2014. Research Design: Qualitative, Quantitative, and Mied Maethod Aprrroach (4th Ed). London: Sage Publication, Inc.

Hamidi. 2010. Metode Penelitian Kualitatif. Malang: UMM Press.

Juditha, Christiany. 2015. Stereotipe dan Prasangka dalam Konflik Etnis Tionghoa dan Bugis Makassar. Jurnal Ilmu Komunikasi. Volume 12: 12-14.

Liliweri, Alo. 2017. Komunikasi Antarpersonal. Jakarta: Prenada Media Goup (Kencana).

Liliweri, Alo. 2018. Prasangka, Konflik Dan Komunikasi Antarbudaya. Jakarta: Kencana.
Miles, Huberman \&. Saldana. 2014. Qualitative Data Analysis. America: SAGE Publications.

Purwasito, Andrik. 2015. Komunikasi Multikultural. Yogyakarta: Pustaka Pelajar.

Rumondor, Feybe H, Paputungan, Ridwan \& Tangkudung, Ridwan 2014. Stereotipe Suku Minahasa Terhadap Etnis Papua (Studi Komunikasi Antarbudaya pada Mahasiswa Fakultas Ilmu Sosial dan Ilmu Politik Universitas Sam Ratulangi),Acta Diurna, Volume 3: 34.

Samovar dkk. 2010. Komunikasi Lintas Budaya (Terjemahan). Jakarta: Salemba Humanika.

Suherli. 2017. Dinamika Interaksi Sosial pada Komunitas Marginal di Pedesaan (Studi Etnografi Komunikasi Masyarakat Tallas di Desa Samasundu Sulawesi Barat: 1-4.

Yin, R. K. 2008. Case Study Research: Design and Methods. Sage Publications. 
42 | Jurnal Komunikasi, Vol. 15 No. 01, Maret 2021: 29-42 